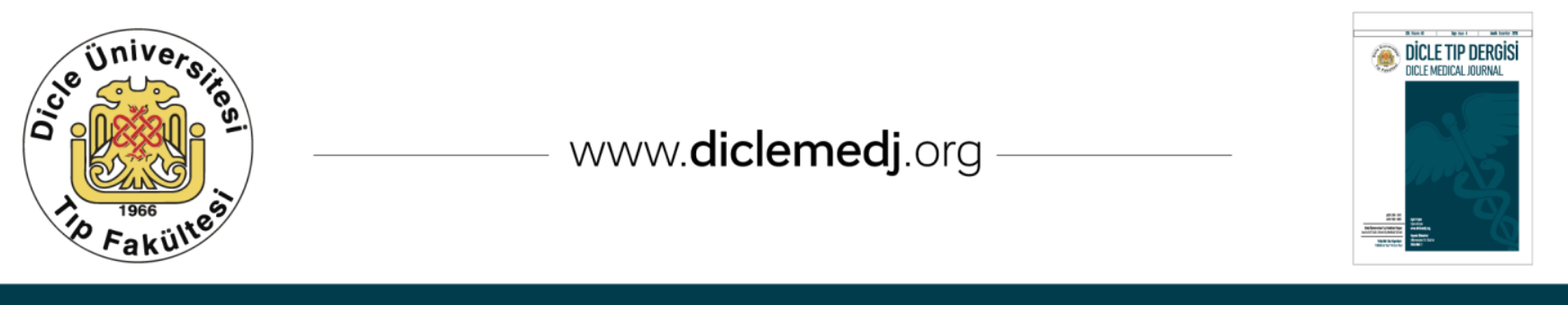

Özgün Araștırma / Original Article

\title{
The effect of oral micronized progesterone on first trimester screening test markers and neonatal outcome
}

\author{
Ilknur Col Madendag ${ }^{1}$, Yusuf Madendag², Mehmet Ak ${ }^{3}$, Erdem Sahin ${ }^{4}$, \\ Mefkure Eraslan Sahin 5 \\ 1 Dept of Obstetrics and Gynecology, Health Sci Univ Kayseri Education and Research Hospital, Kayseri, Turkey ORCID: 0000-0001-6700-2236 \\ 2 Dept of Obstetrics and Gynecology, Erciyes University Medicine Faculty, Kayseri, Turkey ORCID: 0000-0002-7622-2991 \\ 3 Dept of Obstetrics and Gynecology, Health Sci Univ Kayseri Education and Research Hospital, Kayseri, Turkey ORCID: 0000-0003-3384-0586 \\ 4 Dept of Obstetrics and Gynecology, Health Sci Univ Sivas Sarkisla Government Hospital, Sivas, Turkey ORCID: 0000-00019492-6223 \\ 5 Dept of Obstetrics and Gynecology, Health Sci Univ Sivas Sarkisla Government Hospital, Sivas, Turkey ORCID: 0000-0001-6484-9132
}

Received: 07.09.2018; Revised: 07.12.2018; Accepted: 04.01.2019

\begin{abstract}
Objective: It was aimed to investigate whether or not nuchal translucency(NT) thickness, maternal serum free betahuman chorionic gonadotropin( $\beta$-hCG) and pregnancy-associated plasma protein-A(PAPP-A) levels may affected by the use of oral micronized progesterone(OMP) in first trimester pregnancies. Also we aimed to evaluate pregnancy outcome in pregnant women using OMP.

Method: This study was performed retrospectively including 1192 pregnant women, between January 2015 and August 2017. Body mass index(BMI), maternal and gestational age, levels of maternal serum PAPP-A and free $\beta$-hCG, NT measurement and the crown-rump length(CRL), fetal sex, fetal birth weight, Apgar score 5thminute $<7$ and admission to neonatal intensive care unit(NICU) were evaluated.

Results: Maternal characteristics, ultrasound and biochemical parameters, fetal characteristics and neonatal outcome were evaluated. There was no statistically significant difference for maternal age, BMI, gestational age, PAPP-A, $\beta$-hCG, CRL, NT thickness, fetal sex, fetal birth weight, Apgar score 5th minute $<7$ and the number of admission to NICU during the first 28 days.
\end{abstract}

DOI: 10.5798/dicletip.539903

Yazışma Adresi / Correspondence: Yusuf Madendag, This study was conducted in Department of Obstetrics and Gynecology, Health Sciences University Kayseri Education and Research Hospital, Kayseri Turkey Postal code: 38090 e-mail: yusufmadendag@gmail.com 
Conclusions: Our results suggest that in clinical practice, 1) it seems that using OMP cannot affect on NT, CRL and birth weight. 2) OMP cannot adversely affect on production of PAPP-A and $\beta$-hCG in vivo. 3) NT, serum PAPP-A and $\beta$-hCG levels and MoM values, which are markers of the first trimester screening test, do not change by using OMP. Therefore using OMP cannot affect reliability of the first trimester screening test in pregnancy with threatened abortion. 4) OMP does not look like adversely affect on poor neonatal outcome.

Keywords: Nuchal translucency measurement, prenatal diagnosis, progesterone, threatened abortion, pregnancyassociated plasma protein-a.

\section{Oral mikronize progesteronun ilk trimester tarama belirteçlerine ve yeni doğan sonuçlarına etkisi}

\section{Öz}

Amaç: ilk trimester gebeliklerde kullanılan oral mikronize progesteronun (OMP), ilk trimester tarama belirteçleri olan; ense saydamlığı kalınlığı, anne serum beta-insan koryonik gonadotropin $(\beta-h C G)$ ve gebelikle ilişkili plazma protein-A (PAPP-A) düzeylerine etki edip etmediğinin araştırılması amaçlandı. Ayrıca, OMP kullanan gebe kadınlarda yenidoğan sonuçlarını değerlendirmeyi amaçladık.

Yöntemler: Bu çalışma Ocak 2015-Ağustos 2017 tarihleri arasında 1192 gebe kadın dahil olmak üzere retrospektif olarak yapıldı. Vücut kitle indeksi (VKi), maternal ve gestasyonel yaş, anne serum PAPP-A ve serbest $\beta$-hCG düzeyleri, ense saydamlığı ve ölçümü baş-popo uzunluğu (CRL) ölçümü, fetal cinsiyet, fetal doğum ağırlı̆̆, Apgar skoru 5.dakika< 7 ve yenidoğan yoğun bakım ünitesine kabul edilme sayısı araştırıldı. İstatistiksel olarak analiz edildi.

Bulgular: Maternal özellikler, ultrason ve biyokimyasal parametreler, fetal özellikler ve neonatal sonuçlar değerlendirildi. Maternal yaş, VKİ, gestasyonel yaş, PAPP-A, $\beta$-hCG, CRL, ense kalınlığı, fetal cinsiyet, fetal doğum ağırlı̆̆ı, Apgar skoru 5. dakika <7 ve ilk 28 gün boyunca yenidoğan yoğun bakıma kabul sayıları açısından gruplar arasında istatistiksel olarak anlamlı fark yoktu.

Sonuç: Elde ettiğimiz sonuçlar klinik pratikte, 1) OMP'nin ense kalınlığı, CRL ve doğum ağırlığını etkilemediği 2) OMP, in vivo PAPP-A ve $\beta$-hCG'nin üretimini olumsuz yönde etkilemediği 3) Birinci trimester tarama testinin belirteçleri olan ense kalınlığı, serum PAPP-A ve $\beta$-hCG seviyeleri ve MoM değerleri OMP kullanıldığında değişmedi. Bu nedenle düşük tehdidi olan gebelerde OMP'nin kullanılması, gebelikte ilk trimester tarama testinin güvenilirliğini etkilemediğini düşünmekteyiz. 4) OMP, kötü neonatal sonuçları olumsuz yönde etkilemiyor gibi görünmektedir.

Anahtar Kelimeler: Ense kalınlığı ölçümü, prenatal tanı, progesteron, düşük tehdidi, PAPP-A.

\section{INTRODUCTION}

First trimester screening test for trisomy 13, 18 and 21 is usually applied using fetal nuchal translucency (NT) thickness, which is measured sonographically, free beta-human chorionic gonadotropin ( $\beta$-hCG), and pregnancy-associated plasma protein-A (PAPPA), which are measured biochemically from maternal serum between 11th and 14th weeks of gestation. This test can detect about $90 \%$ of trisomy 21 pregnancies with a false positive rate of $5 \% 1,2$. However PAPP-A and free $\beta$-hCG can be affected from some maternal factors such as maternal drug intake, method of conception, maternal weight, gestational age, ethnicity and tobacco use. Therefore these patient specific factors are taken into account while the fetal anomaly risk is calculated ${ }^{1,3}$.

Progesterone is commonly used as a drug to support pregnancy in threatened abortion4-6, which is seen till the first 21th gestational week with bleeding without the opening of the uterine cervix and emerges in $15-20 \%$ of pregnancies during first trimester 7,8 . Progesterone is necessary for implantation, embryonic and fetal improvement and placentation. Therefore it may be affect fetus, 
placenta or some biochemical factors released from cyto- or syncytiotrophoblast ${ }^{9}$.

According to recent studies it has been showed that exogenous progesterone may increase placental volume10 and maternal serum PAPPA levels ${ }^{11}$. Free $\beta$-hCG and PAPP-A are mostly released from placenta and progesterone can positively affect the placenta ${ }^{12}$, hence secretion of $\beta$-hCG and PAPP-A can be affected by exogenous progesterone. There are few investigations about effect of exogenous progesterone on PAPP-A and free $\beta$-hCG in the literature ${ }^{12-14}$. In the present study it was aimed to investigate whether or not NT thickness, maternal serum PAPP-A and free $\beta$-hCG levels can affected by the use of oral micronized progesterone (OMP) in first trimester pregnancies. Also in this study we aimed to evaluate pregnancy outcome in pregnant women using OMP.

\section{METHODS}

This study was performed retrospectively including 1192 pregnant women; all of them were Caucasian, between January 2015 and August 2017 in a university hospital and with approval of the Institutional Review Board (2017/475). All demographic characteristics of study patients were obtained from hospital database. These were body mass index (BMI), maternal and gestational age, all at the time of screening, levels of maternal serum PAPP-A and free $\beta$-hCG, the crown-rump length (CRL), and NT thickness. Also fetal sex, fetal birth weight, Apgar score 5th minute $<7$ and admission to neonatal intensive care unit (NICU) during the first 28 days were evaluated.

All study subjects were included patients who both examined throughout their pregnancy in our clinic and performed first trimester screening test at 11-14th weeks of gestation and delivered in our hospital. However high risk pregnancy such as diabetes mellitus, body mass index $>30 \mathrm{~kg} / \mathrm{m} 2$, hypertension, fetal growth retardation, fetal anomaly, chronic liver disease, endocrine diseases and multiple pregnancy were excluded from this study. Also miscarriages were excluded from this study. All the patients used folic acid, iron or multivitamin preparations, and those who were using other medications and tobacco were not included in the study.

To measure levels of free $\beta$-HCG and PAPP-A in maternal serum samples were used ImmuliteOne® system kits (Siemens Medical Solutions Diagnostics Limited, United Kingdom), which based on the chemiluminescence method, and device of Immulite 2000 (Diagnostic Products Corporation, ABD). NT thickness was measured ultrasonically as millimeter between 11-14th weeks of gestation when the fetus was in normal longitudinal CRL measurement position. The value was recorded as the multiple of the median (MoM), values were adjusted for age, weight and gestational week. All NT thickness measurements were performed transabdominally with Toshiba Xario (Toshiba Medical Systems Corporation, Japan) by two experienced radiologist. The first trimester screening test was calculated using the PRISCA 4.0 (Prenatal Risk Calculator, TYPOLOG Software / GmBH, Hamburg, Germany).

There were two groups (progesterone and control group) in this study. The progesterone group included pregnant women who were diagnosed TA and given $400 \mathrm{mg} /$ day OMP for treatment of TA at least 30 days.4-6 TA was diagnosed when existence of vaginal bleeding, with/without abdominal pain, while the cervix was closed and the fetus was alive in the uterine cavity ${ }^{10}$. The control group included healthy pregnant women.

\section{Statistics}

The Kolmogorov-Smirnov test was used for testing of the normality guess of the data, and the variance homogeneity guess was tried with performing the Levene test. Valuations were 
stated as mean \pm standard deviation or median (25th percentile-75th percentile). Parametric collations were performed using a t-test, and nonparametric collations were performed using the Mann-Whitney $\mathrm{U}$ test. Minitab 16 (Minitab Inc.; State College, PA, USA) program was used for all comparisons, and it was considered statistically significant when $\mathrm{P}$ value less than 0.05 .

\section{RESULTS}

Totally 1192 pregnant women were evaluated for the present study. 248 of them were included to progesterone using group because they took $400 \mathrm{mg} /$ day OMP for treatment of TA. 944 of them were evaluated as the healthy control group. Comparisons of maternal characteristics were showed in Table 1. All maternal characteristics such as maternal age, BMI, gravidity and gestational week at the time of screening had no statistically significant difference between groups.

Table 1. Comparisons of maternal characteristics.

\begin{tabular}{|lccc|}
\hline & $\begin{array}{c}\text { Progesterone } \\
\text { using group } \\
(\boldsymbol{n}: \text { 248 })\end{array}$ & $\begin{array}{c}\text { Control group } \\
(\boldsymbol{n}: \text { 944) }\end{array}$ & p-value \\
\hline $\begin{array}{l}\text { Maternal Age } \\
\text { (years) }\end{array}$ & $27.10 \pm 5.39$ & $26.73 \pm 6.00$ & 0.642 \\
$\begin{array}{l}\text { Maternal BMI } \\
\left(\mathrm{kg} / \mathrm{m}^{2}\right)\end{array}$ & 24.9 & 25.1 & \\
Gravidity & $(23.9-29.1)$ & $(23.7-28.8)$ & 0.464 \\
$\begin{array}{l}\text { Gestational week at } \\
\text { the time of }\end{array}$ & $2(1-3)$ & $2(2-3)$ & 0.270 \\
screening & 12 & 12 & \\
\hline
\end{tabular}

Values are expressed as mean \pm standard deviation or median (25th percentile-75th percentile). BMI, body mass index.

Comparisons of ultrasound and biochemical parameters were showed in Table 2. No statistically significant difference was found in terms of NT, CRL, PAPP-A and $\beta$-hCG between groups.
Also in the present study fetal characteristics and poor neonatal outcome were evaluated (Table 3). There was no statistically significant difference in terms of fetal sex, fetal birth weight, Apgar score 5th minute $<7$ and the number of admission to NICU between groups.

Table 2: Comparisons of ultrasound and biochemical parameters.

\begin{tabular}{|lccc|}
\hline & $\begin{array}{c}\text { Progesterone using } \\
\text { group (n: 248) }\end{array}$ & $\begin{array}{c}\text { Control group } \\
(\boldsymbol{n}: \text { 944) }\end{array}$ & p-value \\
\hline NT MoM & 0.83 & 0.78 & 0.308 \\
CRL lenght (mm) & $62(54-68)$ & $64.5(58-70)$ & 0.052 \\
PAPP-A (mlU/ml) & $3.51 \pm 2.50$ & $3.84 \pm 2.63$ & \\
PAPP-A MoM & 0.98 & 0.97 & 0.361 \\
B-hCG (ng/ml) & $(0.72-1.37)$ & $(0.68-1.41)$ & 0.753 \\
B-hCG MoM & $40.4 \pm 25.0$ & $41.3 \pm 34.9$ & 0.821 \\
& 0.86 & 0.88 & 0.756 \\
\hline
\end{tabular}

Values are expressed as mean \pm standard deviation or median (25th percentile-75th percentile). NT, nuchal translucency; CRL, crownrump length; PAPP-A, pregnancy-associated plasma protein-A; $\beta$ hCG, free beta-human chorionic gonadotropin; MoM, multiple of the median.

Table 3: Comparisons of fetal characteristics and neonatal outcome.

\begin{tabular}{|lccc|}
\hline & $\begin{array}{c}\text { Progesterone using } \\
\text { group (n: 248) }\end{array}$ & $\begin{array}{c}\text { Control group } \\
(\text { n: 944) }\end{array}$ & p-value \\
\hline Fetal sex & $\begin{array}{c}\text { Male 122 } 470 \\
(49.2 \%)\end{array}$ & $\begin{array}{c}(49.8 \%) \\
\text { Female 126 } \\
\text { Female 474 }\end{array}$ & NS \\
Fetal birth- & $(50.8 \%)$ & $(50.2 \%)$ & \\
weight(g) & $3087 \pm 380$ & $3183 \pm 382$ & 0.080 \\
Apgar 5. & & & \\
minute $<7$ & $7(2.8 \%)$ & $25(2.6 \%)$ & 0.868 \\
Admission to & & & \\
NICU & & $33(3.6 \%)$ & 0.104 \\
(during the first & $12(4.8 \%)$ & & \\
28 days) & & & \\
\hline
\end{tabular}

Values are expressed as mean \pm standard deviation or $\mathrm{n} \%$. NS, not significant; NICU, neonatal intensive care unit. 


\section{DISCUSSION}

Progesterone is necessary for implantation, placenta and fetal development ${ }^{9}$. Recently OMP is widely used to maintain pregnancy against to TA4-6, though there is not enough evidence about the use of progesterone for treatment of TA. In the present study, we found that there was no statistically significant difference in terms of maternal age, maternal weight, gravidity, gestational week at the time of screening, CRL, fetal gender and birth weight values between groups. Hence both the progesterone and the control group were homogenous. All these details increase power of the study.

In 2014 Wang et al. showed that progesterone could increase levels of PAPP-A in their both in vivo and in vitro study and they speculated that progesterone was up-regulate PAPP-A, and they added that the PAPP-A expression was increased in both gene and protein level of trophoblastic cells; while the PAPPA expression decreased after RU486 (mifepristone, an antiprogesterone agent) treatment. Nevertheless, progesterone improved the PAPP-A expression by RU486 inhibition ${ }^{11}$. According to that study, we hypothesized that if progesterone increase serum PAPP-A level, the result of the first trimester screening test may be affected, because of the rising levels of PAPP-A, among pregnant women using OMP. However we found that there was no statistically significant difference for both serum PAPP-A levels and PAPP-A MoM values between groups according to the present study results. The mean serum PAPP-A level was $3.51 \pm 2.50 \mathrm{mlU} / \mathrm{ml}$ in the progesterone using group and was $3.84 \pm 2.63 \mathrm{mlU} / \mathrm{ml}$ in the control group ( $\mathrm{p}=0.361$ ).

There are a few studies investigating effect of progesterone on NT, PAPP-A and $\beta$-hCG. Kalem et all. (2018) found that NT (in mm. not as MoM) was higher in progesterone group while PAPP-A and free $\beta$-hCG were similar between groups ${ }^{14}$. Kececioglu et all. (2016) showed that NT (MoM) and free $\beta$-hCG (MoM) were higher in progesterone group while PAPP-A (MoM) was similar between groups ${ }^{13}$. Giorlandino et all. (2015) compared only NT between groups with 3582 patients and found that NT (MoM) in 11th weeks of gestation was higher in the progesteron group while NT in 12-14th weeks of gestation was similar between groups ${ }^{12}$. In the present study NT, serum PAPP-A and $\beta$-hCG levels and MoM values, which are markers of the first trimester screening test, did not change by using OMP. Therefore using OMP cannot affect reliability of the first trimester screening test in pregnancies with threatened abortion. It seems that PAPP-A is similar between groups in many studies. However we can speculate for the different results of previous studies that previous similar studies had some limitations and different methodology and different demographic characteristics of patients. These were maternal age, maternal weight, using tobacco, different race etc. Most of the important factor was that the progesterone group of other previous studies had the number of abortion being higher and different progesterone formulation, route of administration and dose regimen.

Also in the present study we evaluated effect of OMP on poor neonatal outcome by comparing Apgar score 5th minute $<7$ and the number of admission to NICU between groups. No statistically significant difference was found in terms of poor neonatal outcome between groups.

\section{CONCLUSION}

According to the present study results,

1. It seems that using OMP cannot affect on NT, CRL and birth weight.

2. OMP cannot adversely affect on production of PAPP-A and $\beta$-hCG in vivo. 
3. NT, serum PAPP-A and $\beta$-hCG levels and MoM values, which are markers of the first trimester screening test, do not change by using OMP. Therefore using OMP cannot affect reliability of the first trimester screening test in pregnancy with threatened abortion.

4. OMP does not look like adversely affect on poor neonatal outcome.

Declaration of Conflicting Interests: The authors declare that they have no conflict of interest.

Financial Disclosure: No financial support was received.

\section{REFERENCES}

1. Alldred SK, Takwoingi Y, Guo B, et all. First trimester ultrasound tests alone or in combination with first trimester serum tests for Down's syndrome screening. Cochrane Database of Systematic Reviews 2017: 3.

2. Nicolaides KH, Spencer K, Avgidou K, Faiola S, Falcon O. Multicenter study of first-trimester screening for trisomy 21 in 75821 pregnancies: results and estimation of the potential impact of individual riskorientated two-stage first-trimester screening. Ultrasound Obstet Gynecol. 2005; 25: 221-6.

3. Liao AW, Heath V, Kametas N, Spencer K, Nicolaides KH. First-trimester screening for trisomy 21 in singleton pregnancies achieved by assisted reproduction. Hum Reprod. 2001; 16: 501-1504.

4. Walch KT, Huber JC. Progesterone for recurrent miscarriage: truth and deceptions. Best Pract Res Clin Obstet Gynaecol. 2008; 22: 375-89.
5. Sotiriadis A, Papatheodorou S, Makrydimas G. Threatened miscarriage: evaluation and management. Brid Med J. 2004; 329: 152.

6. Czajkowski K, Sienko J, Mogilinski $M$, et all. Uteroplacental circulation in early pregnancy complicated by threatened abortion supplemented with vaginal micronized progesterone or oral dydrogesterone. Fertil Steril. 2007; 87: 613.

7. Weiss JL, Malone FD, Vidaver J, et al. Threatened abortion: a risk factor for poor pregnancy outcome, a population-based screening study. Am J Obstet Gynecol 2004; 190: 745.

8. Alp M, Diclehan 0. Tekrarlayan spontan abortusları olan çiftlerde genetik araştırmalar. Dicle Tıp Derg. 2006; 33: 71-80.

9. Dunn CL, Kelly RW, Critchley HO. Decidualization of the human endometrial stromal cell: an enigmatic transformation. Reprod Biomed Online. 2003;7: 151.

10. Turgal M, Aydin E, Ozyuncu O. Effect of micronized progesterone on fetal-placental volume in first-trimester threatened abortion. J Clin Ultrasound. 2017; 45: 14-9.

11. Wang J, Liu S, Qin HM, Zhao Y, Wang XQ, and Yan Q. Pregnancy-associated plasma protein A up-regulated by progesterone promotes adhesion and proliferation of trophoblastic cells. Int J Clin Exp path. 2014; 7: 142737.

12. Giorlandino C, Cignini P, Padula F, et all. Effects of exogenous progesterone on fetal nuchal translucency: an observational prospective study. Am J Obstet Gynecol. 2015; 212: 335-e1.

13. Keçecioğlu M, Tokmak A, Keçecioğlu TS, et all. Does progesterone therapy increase nuchal translucency in women with threatened miscarriage? Ginekol pol. 2016; 87: 390-4.

14. Kalem MN, Kalem Z, Bakırarar B, Ergün A, Gürgan T. The effect of progesterone use in the first trimester on fetal nuchal translucency. J Turk Ger Gynecol Assoc. 2018; 19: 29. 